\title{
Keterlibatan Orang Tua dalam Pembelajaran Jarak Jauh pada Pendidikan Anak Usia Dini
}

\author{
Maria Liliana Yohanis ${ }^{1}$, Lara Fridani ${ }^{2}$, Tjipto Sumadi ${ }^{3}$ \\ Pendidikan Anak Usia Dini, Universitas Negeri Jakarta \\ DOI: $\underline{10.31004 / o b s e s i . v 5 i 2.1116}$
}

\begin{abstract}
Abstrak
Pembelajaran Jarak Jauh disebut pembelajaran jarak jauh (distance learning), untuk membedakan dengan sistem pembelajaran jarak dekat atau pembelajaran tatap muka. Penelitian ini bertujuan untuk mendeskripsikan keterlibatan orang tua pada PJJ; menganalisis pengaruh faktor demografi terhadap keterlibatan orang tua dalam PJJ; serta menganalis uji perbedaan antara orang tua pada siswa TK-A dan TK-B. Metode penelitian kuantitatif. Sampel peneltian adalah orang tua siswa pada TK-A dan TK-B di TK Tarakanita, Jakarta Timur. Teknik pengumpulan data melalui survei, dengan instrumen penelitian kuesioner. Teknik analisis data menggunakan analisis deskriptif, analisis regresi linear berganda dengan menggunakan ordinary least square (OLS) dengan perangkat lunak IBM SPSS, serta uji beda dengan menggunakan Kruskal-Willis Test. Hasil penelitian menunjukkan bahwa tingkat keterlibatan orang tua pada PJJ sudah relatif baik; faktor demografi mempengaruhi keterlibatan orang tua; serta tidak terdapat perbedaan keterlibatan orang tua pada TK-A dan TK-B di TK Tarakanita, Jakarta Timur.
\end{abstract}

Kata Kunci: pembelajaran jarak jauh; keterlibatan orang tua; faktor demografi

\begin{abstract}
Distance learning is called distance learning, to distinguish it from close learning systems or face-to-face learning. This study aims to describe parental involvement in PJJ; analyzing the influence of demographic factors on parental involvement in PJJ; and analyzing the difference test between parents of TK-A and TK-B students. Quantitative research methods. The research sample was the parents of students at TK-A and TK-B in TK Tarakanita, East Jakarta. The technique of collecting data through surveys, with a questionnaire research instrument. The data analysis technique used descriptive analysis, multiple linear regression analysis using the ordinary least square (OLS) with IBM SPSS software, and different tests using the KruskalWillis Test. The results showed that the level of parental involvement in PJJ was relatively good; demographic factors influence parental involvement; and there is no difference in parental involvement in TK-A and TK-B in TK Tarakanita, East Jakarta.
\end{abstract}

Keywords: distance learning; parental engagement; demographic factors

Copyright (c) 2021 Maria Liliana Yohanis, Lara Fridani, Tjipto Sumadi

$\triangle$ Corresponding author :

Email Address : email koresponden@gmail.com ( alamat, koresponden )

Received 30 January 2021, Accepted 9 February 2021, Published 25 February 2021 


\section{PENDAHULUAN}

Pandemi Corona Virus Disease 2019 (Covid-19) menjadi masalah global yang harus dihadapi masyarakat dunia. Sampai penelitian ini dilakukan, pandemi Covid-19 belum menunjukkan tanda-tanda akan berakhir, karena kurva Covid-19 dunia masih belum melandai (World Health Organization, 2020). Salah satu dampak pandemi Covid-19 dirasakan pada sektor pendidikan, khususnya pada sistem kegiatan belajar mengajar (KBM). Sebagai konsekuensi pandemi Covid-19, Indonesia memberlakukan sistem Pembelajaran Jarak Jauh (PJJ). PJJ tidak memunginkan KBM berlangsung secara tatap-muka, melainkan melalui daring.

Terkait PJJ akibat pandemi Covid-19, pemerintah Indonesia (c.q Kementerian Pendidikan) mengeluarkan Surat Edaran Mendikbud No. 4 Tahun 2020 tentang Pelaksanaan Kebijakan Pendidikan dalam Masa Darurat Penyebaran Coronavirus Disease 2019 (Covid-19). Butir (2) SE tersebut mengatur mengenai proses belajar dari rumah (BDR) melalui pembelajaran daring/jarak jauh (lebih populer disebut PJJ). Apabila memandang empat butir ketentuan BDR, tampak terdapat penurunan target belajar dan pemakluman dari sistem belajar tatap muka. Proses "Belajar dari Rumah" yang disebut BDR (selanjutnya dalam penulisan ini sebut PJJ, memiliki sejumlah ketentuan (Kemendikbud \& Menteri Pendidikan dan Kebudayaan Republik Indonesia, 2020).

Ketentuan PJJ, empat hal di antaranya adalah: Pertama, PJJ ditujukan untuk memberikan pengalaman belajar yang bermakna bagi siswa, tanpa terbebani tuntutan menuntaskan seluruh capaian untuk kenaikan kelas maupun kelulusan. Kedua, PJJ difokuskan pada pendidikan kecakapan hidup antara lain mengenai pandemi Covid-19. Ketiga, Aktivitas PJJ dapat bervariasi antar siswa, dengan mempertimbangkan minat, kondisi, termasuk mempertimbangkan kesenjangan akses/ fasilitas belajar di rumah. Keempat, bukti atau produk aktivitas belajar dari rumah diberi umpan balik yang bersifat kualitatif dan berguna dari guru, tanpa diharuskan memberi skor nilai kuantitatif.

Secara konseptual, istilah PJJ dikategorikan sebagai pembelajaran online (online learning) untuk membedakannya dengan pembelajaran secara offline (offline learing) (Stevens \& Borup, 2015). Konsep PJJ juga disebut pembelajaran jarak jauh (distance learning), untuk membedakannya dengan sistem pembelajaran jarak dekat atau pembelajaran tatap muka (Fedina et al., 2017). Pada penelitian ini konsep PJJ (atau bisa diartikan sebagai online learning maupun distance learning, mengingat kedua elemen pada kedua konsep tersebut, yakni elemen jarak jauh (distance) dan elemen daring (online), digunakan dalam PJJ di Indonesia pada masa pandemi Coviod-19.

Bagaimana pelaksanaan PJJ pada masa pandemi Covid-1, hal ini terungkap antara lain dari survei dalam jaringan (daring) yang dilakukan oleh Kementerian Pendidikan dan Kebudayaan dalam rentang waktu 13-22 Mei 2020. Survei ini melibatkan 38.109 siswa dan 46.547 orang tua pada seluruh jenjang pendidikan, di seluruh provinsi di Indonesia. Rentang waktu berikutnya, 18 Mei- 2 Juni 2020, Kemendikbud bekerja sama dengan UNICEF melakukan survei serupa, namun melalui sms gratis terhadap 1.096 siswa dari 602 orang tua, terutama yang berdomisili di daerah "terdepan, terluar, dan tertinggal " (3-T) (Kemendikbud, 2020).

Survei itu menemukan data bahwa baik di wilayah 3T maupun non-3T, mayoritas (96,6 persen) siswa belajar sepenuhnya di rumah. Hanya 3,3 persen siswa yang belajar bergantian di rumah dan di sekolah. Sebanyak 0,1 persen siswa belajar penuh di sekolah, karena tidak ada yang mendampingi belajar di rumah. Siswa-siswa tersebut berdomisili di 3-T yang tidak terdampak Covid-19. Melalui survei ini diketahui bahwa 90 persen orang tua mendampingi anaknya belajar dari rumah di semua jenjang pendidikan (Kemendikbud, 2020).

Suatu hal menarik dari survei itu adalah mayoritas (90 persen) orang tua mendampingi anaknya pada PJJ. Hal ini berarti orang tua mendampingi anaknya dalam PJJ merupakan sebuah fenomena yang hampir merata terjadi di seluruh provinsi di Indonesia. Fenomena keterlibatan orang tua (parent engagement) dalam PJJ menjadi tema penelitian ini. Secara 
teoritis, bagaimana bentuk keterlibatan orang tua dalam PJJ, sejumlah penulis mengemukakan elemen-elemen keterlibatan orang tua dalam pembelajaran online.

Sampai dengan penelitian ini dilakukan, terdapat sejumlah penelitian sebelumnya dengan tema PJJ di Indonesia pada masa pandemi Covid-19 dan dipublikasikan tahun 2020. Penelitian PJJ tersebut meliputi kategori umum, dan kategori khusus terkait keterlibatan orang tua dalam PJJ. Penelitian dengan kategori umum antara lain dengan tema efektivitas PJJ (Shadiqien, 2020), tema kepuasan pada pelaksanaan PJJ, tema dampak PJJ pada tingkat stres dan tema pendidikan karakter di lingkungan keluarga selama PJJ (Purandina \& Winaya, 2020).

Terdapat sejumlah penelitian bertema PJJ dengan fokus pada sub-tema peran atau keterlibatan orang tua, antara lain penelitian (Yulianingsih et al., 2020), (Cahyati, N., \& Kusumah, 2020), (Wardhani, T.Z.Y., \& Krisnani, 2020), dan (Lilawati, 2020). Namun terdapat perbedaan dengan penelitian ini, yakni pada: (i) Model operasional variabel keterlibatan ortangtua. Hanya penelitian ini yang menggunakan opererasional variabel keterlibatan orang tua yang merujuk pada model Hoover-Dempsey \& Sandle, (2005) yang diadaptasi (Liu et al., 2010). Keterlibatan orang tua pada model (Hoover-Dempsey, K. V., \& Sandler, 2014) memiliki empat dimensi, yakni encouragement, modeling, reinforcement, dan interaction.

Pengujian model (Hoover-Dempsey, K. V., \& Sandler, 2014) tersebut penting pada setting yang baru (di Indonesia, dan pada masa pandemi Covid-19). Penelitiian Black (2009) dengan menggunakan Hoover-Dempsey dan Sandler (2005) menemukan korelasi positif antara keterlibatan orang tua dengan proksi "parental reinforcement" terhadap grade hasil belajar; dan menemukan korelasi negatif antara proksi "parental instructing" terhadap grade hasil belajar. Hal ini bertentangan dengan penelitian lain menemukan hasil yang sebaliknya. (Borup et al., 2013) menemukan bahwa keterlibatan orang tua dalam PJJ berkorelasi negatif dengan hasil pembelajaran. Hasil penelitian yang menunjukkan pro-kontra ini mendorong penulis untuk melakukan penelitian serupa dalam konteks Indonesia pada masa pandemi Covid-19.

Perbedaan lain penelitian ini dengan penelitian lain keterlibatan orang tua pada masa PJJ (Yulianingsih et al., 2020) (Cahyati, N., \& Kusumah, 2020)(Wardhani, T.Z.Y., \& Krisnani, 2020) dan (Lilawati, 2020) terletak pada analisis regresi. Penelitian ini memasukkan faktor demografi sebagai penentu keterlibatan orang tua. Faktor demografi dimaksud adalah faktor demografi orang tua yang menyangkut antara lain tingkat pendidikan formal dan status sosial ekonomi orang tua. Faktor demografi orang tua tersebut disaumsikan berpengaruh pada keterlibatan orang tua, karena hubungan awal orang tua-anak (early parent-child relationship) merupakan hal yang penting dalam pengembangan karir anak, khususnya menekankan pada lingkungan yang diberikan orang tua kepada anak (O'Brien, 2001).

Model expectancy-value Eccles, menunjukkan bahwa orang tua merupakan seorang role model yang menguatkan, menyediakan informasi, kekayaan, dan peluang untuk anak-anak mereka. Keterlibatan orang tua dengan anak menunjukkan pengaruh terhadap motivasi dan perilaku anak dalam belajar. Hal ini termasuk juga status ekonomi sosial orang tua. Status ekonomi social (socioeconomic status/SES) merupakan faktor yang mempengaruhi pencapaian anak-anak (Palmer, AG and Potter, 2007). Penelitian membuktikan bahwa hubungan kemiskinan dan status sosial ekonomi yang rendah membawa pengaruh buruk bagi anak termasuk IQ rendah, pencapaian edukasi yang rendah, dan masalah emosi-sosial.

Perbedaan lain penelitian ini dengan peneltian sebelumnya, selain menggunakan analisis regresi linear berganda, teknik analisis penelitian ini juga menggunakan analisis perbandingan dengan uji beda, serta analisis research $\mathcal{E}$ development $(\mathrm{R} \& \mathrm{D})$. Gabungan ketiga alat analisis tersebut tidak digunakan dalam penelitian-penelitian terdahulu (Yulianingsih et al., 2020) (Cahyati, N., \& Kusumah, 2020) (Wardhani, T.Z.Y., \& Krisnani, 2020) dan (Lilawati, 2020).

Perbedaan lain adalah mengenai lokasi dan subjek penelitian. Penelitian ini hendak menguji bagaimana keterlibatan orang tua (parental engagement) dalam PJJ pada pendidikan anak usia dini pada periode pandemi Covid-19 ini Jakarta, dengan fokus lokasi dan sebjek 
penelitian ini adalah pada orang tuasiswa Taman Kanak-Kanak A (TK-A) dan TK-B Tarakanita 5, Kota Jakarta Timur, Provinsi DKI Jakarta. Penelitian akan menguji sejauh mana faktor demografi mempengaruhi keterlibatan orang tua tersebut. Faktor demografi ini penting untuk diteliti karena diasumsikan keterlibatan orang tua dalam pembelajaran tersebut berbeda-beda ditinjau dari aspek demografi.

\section{METODOLOGI}

Penelitian ini menggunakan pendekatan kuantitatif. Tipe penelitian adalah tipe kausal asimetri yang berarti tipe penelitian kausal yang pengaruhanya hanya satu arah, yakni perubahan pada suatu variabel (variabel independen) berdampak terhadap perubahan pada variabel lain (variabel dependen) (Cooper, D.R., \& Schindler, 2014). Waktu penelitian ini adalah one sho, atau cross sectional yakni tahun 2020-2021. Lokasi penelitian adalah pada Taman Kanak-Kanak (TK) Tarakanita 5 di Jakarta Timur, Provinsi DKI Jakarta. Populasi dalam penelitian ini adalah seluruh orang tua siswa Taman Kanak-Kanak pada TK-Tarakanita, Jakarta Timur, Provinsi DKI Jakarta, pada tahun ajaran 2019/2020, yang setiap siswa diwakili oleh satu orang, yakini ayah atau ibu atau wali. Jumlah siswa TK-A adakah 48 siswa dan jumlah TK-B adalah 50 siswa, sehingga total populasi siswa adalah 98 siswa, yang berarti jumlah opulasi orang tua (dimana setiap siswa diwakili satu orang tua/ wali) adalah 98 orang tua.

Sampel dalam penelitian ini adalah sampel perbandingan, antara orang tua siswa TKA dan orang tua siswa dan siswa TK-B, yang jumlahnya sama dengan total populasi, yakni 98 orang tua. Teknik sampling dalam penelitian ini adalah non-probability sampling, yang dalam penelitian ini dipilih purposive sampling, yang lebih spesifik lagi dari purposive sampling, dalam penelitian ini dipilih judgment smpaling. Alasan pemilihan teknik sampel ini mengingat sampel penelitian ini, yakni semua orang tua siswa TK-A dan TK-B pada TK Trakanita, Jakarta Timur, kelompok target yang spesific (specific target group) yang menmiliki informasi spesifik (Sekaran, U., 2016), yakni keterlibatan orang tua siswa pada kedua kelas tersebut.

Pelaksanaan teknik pengumpulan sampel tersebut disesuaikan dengan protokol kesehatan Covid-19, dilakukan melalui google form. Tautan (link) dari kuesioner tersebut akan dibagikan kepada semua orang tua siswa TK-A dan TK-B melalui whatsApp pada smartphone

Teknik analisis data meliputi: (i) Analisis dekriptif (nilai rata-rata, dan standar deviasi) (Ghozali, 2018) pada kedua variabel penelitian (variabel faktor demografi orang tua; dan variabel keterlibatan orang tua pada PJJ). (ii) Analisis regresi linear berganda (pengaruh faktor dcmografi orang tua terhadap keterlibatan orang tua pada PJJ) (Widarjono, 2013). (iii) Analisis uji beda (menggunakan Kruskal-Willis), antara keterlibatan orang tua siswa pada TK-A dengan orang tua siswa TK-B Tarakanita 5 Jakarta Timur, Provinsi DKI Jakarta. Road map penelitian dapat dilihat pada gambar 1.

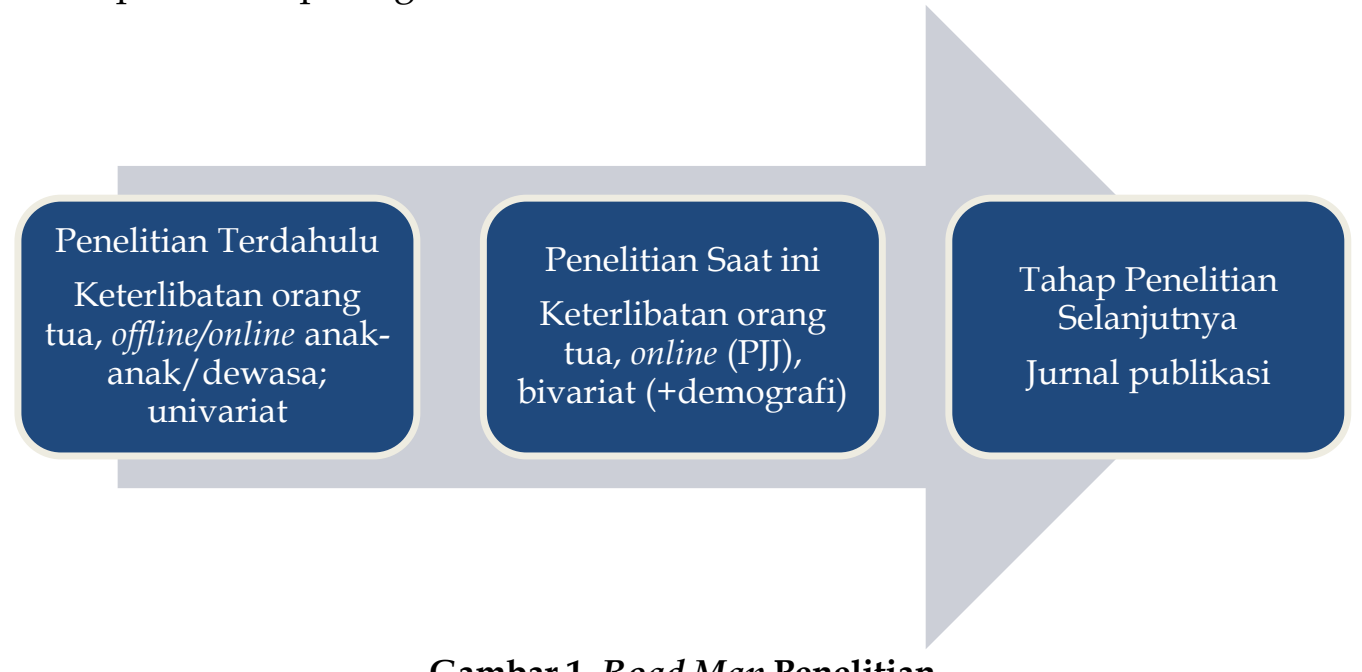

Gambar 1. Road Map Penelitian 


\section{HASIL DAN PEMBAHASAN}

\section{Deskripsi Demografi Responden}

Dilihat dari jenis kelamin orang tua siswa, masing-masing kelas (TK-A dan TK-B) sama-sama didominasi wanita (TK-A 91,20\% dan TK-B 91,40\%). Usia orang tua kedua kelas memiliki kecenderungan sama bahwa terbanyak adalah kategori usia 35-40 tahun (TK-A mencakup 55,90\% dan TK-B mencakaup 60,0\%), Ranking anak di kelas terbanyak masuk kategori ranking 6-10, masing-masing 35,30\% (TK-A) dan 34,3\% (TK-B). Kelas sosial orang tua, terbanyak adalah manajer/teknikal, masing-masing 50,00\% (TK-A) dan 48,6\% (TK-B). Pendidikan formal responden mayoritas lulusan program sarjana strata 1, masing-masing 70,60\% (TK-A), dan 71,40\% (TK-B).

Demikian pula terdapat kecenderungan yang identik antara orang tua mereka dalam hal jumlah orang yang tinggal serumah dengan anak, masing-masing yakni 4-6 orang untuk orang tua siswa TK-A dan TK-B. Begitu pula jumlah saudara kandung dari anak, terdapat kemiripan dalam hal seorang saudara kandung, maupun 2-3 saudara kandung. Pada orang tua TK-A terdapat 12 orang tua $(35,30 \%)$, siswa bersangkutan memiliki seorang saudara kandung, dan 11 orang tua $(32,40 \%)$ siswa bersangkutan memiliki 2-3 orang saudara kandung. Kecenderungan yang identik pada TK-B, yakni terdapat 13 orang tua $(37,10 \%)$, siswa bersangkutan memiliki seorang saudara kandung, 11 orang tua $(31,40 \%)$ siswa bersangkutan memiliki 2-3 orang saudara kandung.

Kecenderungan yang berbeda antara orang tua siswa Kelas TK-A dengan TK-B adalah dalam hal status kepemilikan rumah. Rumah milik sendiri lebih banyak dimiliki orang tua TK-B $(60,00 \%)$ berbanding orang tua siswa TK-A $(0,00 \%)$. Sementara itu rumah dinas banyak dimiliki oleh orang tua siswa kelas TK-A $(64,70 \%)$ berbanding orang tua siswa kelas TK-B $(2,90 \%)$. Terdapat persamaan antara orangtu TK-A dan TK-B perihal status rumah kontrak, masing-maisng 20,60\% (TK-A) dan 20,00 \% (TK-B).

Kecenderungan yang berbeda juga mengenai Kepemilikan komputer (personal computer, PC)/ laptop pada keluarga. Pada kategori keluarga memiliki 1 PC, > 1 smartphone, tapi tidak memiliki laptop; terdapat 12 orang tua (35,30\%) pada TK-A; sedangkan pada TK-B tidak ada seorang pun orang tua yang masuk kategori ini. Hanya saja ketika dibandingkan pada lategori "memiliki 1 laptop, > 1 smartphone, tapi tidak memiliki PC" jutsru orang tua kelas TK-B lebih banyak (16 orang atau 45,70\%) daripada TK-A yang berjumlah 11 orang tua $(32,40 \%)$.

\section{Deskripsi Variabel}

Deskripsi variabel ini menilai nilai rata-rata (mean), sehingga variabel yang dideskripsikan adalah yang diukur secara persepsional dengan skala ordinal (skala Likert 15), yakin variabel keterlibatan orang tua dalam PJJ yang terdiri atas empat dimensi, yakni dimensi encouragement, modeling, reinforcement, dan interaction.

Tabel 2 Deskripsi Dimensi Encouragement

\begin{tabular}{llllll}
\hline $\begin{array}{l}\text { Nomor } \\
\text { Item }\end{array}$ & Nilai Rata-rata & Nomor Item & Nilai Rata-rata & Nomor Item & $\begin{array}{l}\text { Nilai Rata- } \\
\text { rata }\end{array}$ \\
\hline 1 & 3,5362 & 6 & 4,1449 & 11 & 4,1014 \\
2 & 4,0580 & 7 & 4,3188 & 12 & 4,4058 \\
3 & 4,2899 & 8 & 4,5507 & 13 & 4,1449 \\
4 & 4,2609 & 9 & 4,1739 & & \\
5 & 4,1739 & 10 & 4,5217 & & $\mathbf{4 , 2 0 6 2}$ \\
\hline
\end{tabular}


Tabel 2 menyajikan deskripsi dimensi encouregement dengan 13 indikator (item 1 s.d item 13), Kecuali item 1, maka kesemua item sisanya memiliki nilai rata-rata di atas 4,00. Secara total, nilai rata-rata dimensi encouregement adalah 4,2062. Nilai rata-rata ini, jika skala 1-5 dengan interval 1,8, maka nilai rata-rata 4,2062 sudah termasuk kategori sangat setuju. Hal ini bermakna respoden sudah dengan relatif bisa memerankan dimensi encouregement pada keterlibatan orang tua dalam membantu anak TK mereka dalam PJJ.

Tabel 3 Deskripsi Dimensi Modeling

\begin{tabular}{|c|c|c|c|c|c|c|}
\hline Nomor Item & $\begin{array}{l}\text { Nilai } \\
\text { rata }\end{array}$ & Rata- & Nomor Item & $\begin{array}{l}\text { Nilai Rata- } \\
\text { rata }\end{array}$ & $\begin{array}{l}\text { Nomor } \\
\text { Item }\end{array}$ & $\begin{array}{l}\text { Nilai Rata- } \\
\text { rata }\end{array}$ \\
\hline 14 & 4,4058 & & 18 & 4,0290 & 22 & 4,4058 \\
\hline 15 & 4,2899 & & 19 & 4,2319 & 23 & 4,4058 \\
\hline 16 & 4,4058 & & 20 & 4,3768 & & \\
\hline 17 & 4,4348 & & 21 & 4,5217 & & \\
\hline
\end{tabular}

Tabel 3 menyajikan deskripsi dimensi modeling dengan 10 indikator (item 14 s.d item 23), Kesemua item dimensi ini memiliki nilai rata-rata di atas 4,00. Secara total, nilai rata-rata dimensi modeling adalah 4,3507, yang berarti respoden sudah termasuk kategori sangat setuju terhadap item-item dalam modeling. Hal ini bermakna respoden sudah dengan relatif bisa memerankan dimensi modeling pada keterlibatan orang tua dalam membantu anak TK mereka dalam PJJ.

Tabel 4 Deskripsi Dimensi Reinforcement

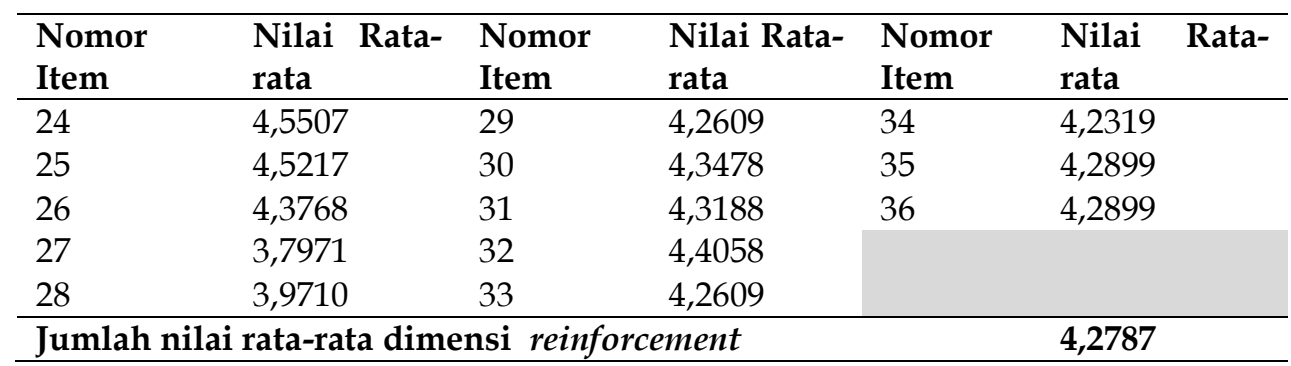

Tabel 4 menyajikan deskripsi dimensi reinforcement dengan 13 indikator (item 24 s.d item 36), Kecuali dua item (item 27 dan item 28), kesemua item dimensi ini memiliki nilai ratarata di atas 4,00. Secara total, nilai rata-rata dimensi modeling adalah 4,2787, yang berarti respoden sudah termasuk kategori sangat setuju terhadap item-item dalam reinforcement. Hal ini bermakna responden sudah dengan relatif bisa memerankan dimensi reinforcement pada keterlibatan orang tua dalam membantu anak TK mereka dalam PJJ.

Tabel 5 Deskripsi Dimensi Interaction

\begin{tabular}{llllll}
\hline $\begin{array}{l}\text { Nomor } \\
\text { Item }\end{array}$ & $\begin{array}{l}\text { Nilai Rata- } \\
\text { rata }\end{array}$ & $\begin{array}{l}\text { Nomor } \\
\text { Item }\end{array}$ & $\begin{array}{l}\text { Nilai Rata- } \\
\text { rata }\end{array}$ & $\begin{array}{l}\text { Nomor } \\
\text { Item }\end{array}$ & $\begin{array}{l}\text { Nilai } \\
\text { rata }\end{array}$ \\
\hline 37 & 4,0000 & 42 & 4,4928 & 47 & 4,1449 \\
38 & 4,2319 & 43 & 4,4928 & 48 & 4,2754 \\
39 & 4,1739 & 44 & 4,3188 & 49 & 4,5217 \\
40 & 4,3478 & 45 & 4,3188 & 50 & 4,5507 \\
41 & 4,1739 & 46 & 4,2174 & 51 & 4,3478 \\
\hline Jumlah nilai rata-rata dimensi & interaction & $\mathbf{4 , 3 0 7 2}$ \\
\hline
\end{tabular}


Tabel 5 menyajikan deskripsi dimensi interaction dengan 15 indikator (item 37 s.d item 51), Kesemua item dimensi ini memiliki nilai rata-rata di atas 4,00. Secara total, nilai rata-rata dimensi interaction adalah 4,3072, yang berarti respoden sudah termasuk kategori sangat setuju terhadap item-item dalam interaction. Hal ini bermakna responden sudah dengan relatif bisa memerankan dimensi interaction pada keterlibatan orang tua dalam membantu anak TK mereka dalam PJJ.

\section{Uji Asumsi Klasik}

Hasil uji asumsi klasik terkait model pengaruh faktor demografi terhadap keterlibatan orang tua dalam PJJ adalah sebagai berikut:

Hasil uji multikolinieritas. Uji multikolinieritas dalam penelitian ini menggunakan uji korelasi Pearson Correlation. Hasilya korelasi antardimensi pada variabel independen (jenis kelamin, usia, ranking di kelas, kelas sosial, pendidikan, rumah orang tua, orang serumah, jumlah saudara kandung, dan kepemilikan komputer) nilai kesemua korelasinya di bawah nilai 0,80 (Widarjono, 2013), maka tidak terdapat multikolinieritas di antara kesembilan dimensi variabel independen.

Hasil uji heteroskedastisitas. Uji heteroskedastisitas dalam penelitian menggunakan karakteristik pola titik-titik (sebaran data) pada scatter-plot. Gambar scatter plot sebagai salah satu output regresi linear berganda menunjukkan bahwa tidak terdapat pola teretentu yang spesifik, ataupun yang terkonsentrasi pada satu kuadran. Titik-titik menyebar di bawah di atas maupun di bawah angko 0 (nol) pada sumbu Y, sehingga kotak scatterpolt dibagi empat bidang, maka keempat bidang tersebut terisi sebaran titik-titik tersebut (Sarwono, 2012). Oleh karena itu dapat disimpulan bahwa model penelitian ini terbebas dari heteroskedastisitas.

Hasil uji autokorelasi. Uji autokorelasi dalam penelitian ini menggunakan uji perbandingan antara nilai Durbin Watson (DW) dengan nilai 4-dl. Nilai DW hasil penelitian ini adalah 2,296. Pada signifikansi alpha 0,05 dengan jumlah data $(\mathrm{n})=69$, diperoleh nilai $\mathrm{dl}=$ 1,5803, dan nuilai $\mathrm{dU}=1,6390$ Berarti nilai 4-dl $=4-1,5803=2,4197$ Nikai DW $(2,296)<$ nilai 4dL $(2,4197)$, sehingga model penelitian ini terbebas dari autokorelasi.

Hasil uji linearitas. Uji linearitas penelitian ini menggunakan perbanduingan antyara nilai "Sig deviation from linaerity" dengan nilai signifikansi alpha 0,05. Hasil uji linearitas antara sembilan dimensi pada variabel independen (jenis kelamin, usia, ranking di kelas, kelas sosial, pendidikan, rumah orang tua, orang serumah, jumlah saudara kandung, dan kepemilikan komputer) dengan variavbel dependen (keterlibatan orang tua pada PJJ). Hasilnya nilai Sig deviation from linaerity" pada tabel ANOVA bernilai 0,244 yang berarti lebih besar daripada signifikansi alpha 0,05 (Widarjono, 2013) (Ghozali, 2018). Hal ini berarti terdapat hubungan linearitas antara variabel demografi dengan sembilan dimensinya itu dengan variabel keterlibatan orang tua dalam PJJ.

Hasil uji normalitas. Uji normalitsa pada penelitian ini menggunakan uji KolmogorovSmirnov. Hasilnya, nilai Asymp.Sig (2-tailed) variabel demografi maupun variabel keterlibatan orang tua pada PJJ, masing-masing adalah 0,070 dan 0,069 yang berarti keduanya lebih besar daripada nilai alpha 0,05 . Hal ini menunjukkan bahwa data dalam penelitian ini berdistribusi normal.

\section{Hasil Regresi Linear Berganda}

Hasil regresi linear berganda penelitian ini adalah sebagai berikut:

Model pengaruh faktor demografi dengan sembilan dimensi (jenis kelamin, usia, ranking di kelas, kelas sosial, pendidikan, rumah orang tua, orang serumah, jumlah saudara kandung, dan kepemilikan komputer) terhadap keterlibatan orang tua dalam PJJ pada kedua kelas sekaligus (TK-A dan TK-B). Hasil penelitian menunjukkan bahwa nilai $R$ square $\left(\mathrm{R}^{2}\right)$ adalah 0,290 $(29,00 \%)$. Hal ini berarti besarnya kontribusi atau pengaruh faktor demografi terhadap keterlibatan orang tua pada PJJ adalah 29,00\%.. Penjelsan sisanya $(100 \%-29,00 \%=$ $71,00 \%$ ) terhadap keterlibatan orang tua pada PJJ dapat dijelasskan oleh variabel lain di luar 
variabel demografi. Nilai F hitung $(2,683)>$ F Tabel $(2,02)$. Nilai sig $(0,011)<$ alpha 0,05 . Hal ini berarti Faktor demografi berpengaruh positif dan signifikan terhadap keterlibatan orang tua pada PJJ pada gabungan orang tua siswa TK-A \& TK-B di TK Tarakanita, Jakarta Timur.

Model pengaruh faktor demografi dengan sembilan dimensi (jenis kelamin, usia, ranking di kelas, kelas sosial, pendidikan, rumah orang tua, orang serumah, jumlah saudara kandung, dan kepemilikan komputer) terhadap keterlibatan orang tua dalam PJJ hanya pada satu kelas, dalam hal ini TK-A, TK Tarakanita, Jakarta Timur. Hasil penelitian menunjukkan bahwa nilai $\mathrm{R}$ square $\left(\mathrm{R}^{2}\right)$ adalah $0,285(28,50 \%)$ Hal ini berarti besarnya kontribusi atau pengaruh faktor demografi terhadap keterlibatan orang tua pada PJJ adalah $28,50 \%$. Penjelasan sisanya $(100 \%-28,50 \%=71,50 \%)$ terhadap keterlibatan orang tua pada PJJ dapat dijelasskan oleh variabel lain di luar variabel demografi. Nilai F hitung $(2,17)>$ F Tabel $(2,02)$. Nilai sig $(0,424)>$ alpha 0,05 . Hal ini berarti Faktor demografi berpengaruh positif namun tidaj signifikan terhadap keterlibatan orang tua pada PJJ pada oranggtua siswa (hanya) TK-A di TK Tarakanita, Jakarta Timur.

Model pengaruh faktor demografi dengan sembilan dimensi (jenis kelamin, usia, ranking di kelas, kelas sosial, pendidikan, rumah orang tua, orang serumah, jumlah saudara kandung, dan kepemilikan komputer) terhadap keterlibatan orang tua dalam PJJ hanya pada satu kelas, dalam hal ini TK-B, TK Tarakanita, Jakarta Timur.

Hasil penelitian menunjukkan bahwa nilai $R$ square $\left(R^{2}\right)$ adalah 0,297 (29,70\%). Hal ini berarti besarnya kontribusi atau pengaruh faktor demografi terhadap keterlibatan orang tua pada PJJ adalah 29,70\%.. Penjelasan sisanya $(100 \%-29,70 \%=70,30 \%)$ terhadap keterlibatan orang tua pada PJJ dapat dijelasskan oleh variabel lain di luar variabel demografi. Nilai $\mathrm{F}$ hitung $(2,683)>$ F Tabel $(2,02)$. Nilai sig $(0,011)<$ alpha 0,05. Hal ini berarti Faktor demografi berpengaruh positif dan signifikan terhadap keterlibatan orang tua pada PJJ pada orang tua siswa (hanya) TK-A di TK Tarakanita, Jakarta Timur.

Hasil regresi tersebut membuktikan kebenaran hipotesis ketiga penelitian ini bahwa faktor demografi mempengaruhi keterlibatan orang tua pada PJJ, baik orang tua hanya siswa TK-A, atau hanya orang tua hanya siswa TK-B, atau orang tua gabungan TK-A dan TK-B, pada TK Tarakanita, Jakarta Timur. Hasil penelitian ini mendukung penelitian sebelumnya seperti penelitian (degli Espinosa et al., 2020), (Fogler et al., 2020), (Bacher-Hicks et al., 2021) (Anzani et al., 2020), (Liu et al., 2010).

\section{Hasil Uji Beda}

Uji beda dalam penelitian ini hendak menguji apakah terdapat perbedaan antara kesembilan dimensi dari variabel demografi dan dimensi variabel keterlibatan orang tua hanya pada orang tua siswa TK-A dan orang tua siswa TK-B. Tabel menunjukkan hasil uji beda dengan Kruskal-Wallis Test. Pengambilan keputusannmya adalah sebagai berikut:

Jika Sig > alpha 0,05, maka H0 diterima, yang berarti tidak terdapat perbedaan di antara aspek yang diuji. Jika Sig < alpha 0,05, maka H0 ditolak, yang berarti terdapat perbedaan di antara aspek yang diuji (Enterprise, 2014).

Tabel 6 menunjukkan hasil uji beda pengaruh kesemibilan dimensi dari faktor demografi terhadap keterlibatan orang tua pada PJJ:

Terkait dimensi dari variabel keterlibatan orang tua pada PJJ, berikut hasil uji beda: dimensi encouregement, nilai sig 0,884 berarti lebih besar daripada alpha 0,05 , sehingga dapat disimpulkan $\mathrm{H} 0$ diterima, yang berarti tidak terdapat perbedaan antara orang tua TK-A maupun TK-B pada dimensi encouregement; dimensi modeling, nilai sig 0,936 berarti lebih besar daripada alpha 0,05, sehingga dapat disimpulkan H0 diterima, yang berarti tidak terdapat perbedaan antara orang tua TK-A maupun TK-B pada dimensi modeling; dimensi reinforcement, nilai sig 0,942 berarti lebih besar daripada alpha 0,05, sehingga dapat disimpulkan $\mathrm{H} 0$ diterima, yang berarti tidak terdapat perbedaan antara orang tua TK-A maupun TK-B pada dimensi reinforcement; serta dimensi instruction, nilai sig 0,866 berarti lebih 
besar daripada alpha 0,05, sehingga dapat disimpulkan H0 diterima, yang berarti tidak terdapat perbedaan antara orang tua TK-A maupun TK-B pada dimensi instruction.

Terkait dimensi dari variabel demografi, berikut hasil uji beda: dimensi jenis kelamin, nilai sig 0,971 berarti lebih besar daripada alpha 0,05, sehingga dapat disimpulkan H0 diterima, yang berarti tidak terdapat perbedaan antara orang tua TK-A maupun TK-B pada dimensi jenis kelamin; dimensi usia, nilai sig 0,488 berarti lebih besar daripada alpha 0,05, sehingga dapat disimpulkan $\mathrm{H} 0$ diterima, yang berarti tidak terdapat perbedaan antara orang tua TK-A maupun TK-B pada dimensi usia; dimensi ranking di kelas, nilai sig 0,871 berarti lebih besar daripada alpha 0,05, sehingga dapat disimpulkan $\mathrm{H} 0$ diterima, yang berarti tidak terdapat perbedaan antara orang tua TK-A maupun TK-B pada dimensi ranking di kelas.

Dimensi kelas sosial, nilai sig 0,856 berarti lebih besar daripada alpha 0,05, sehingga dapat disimpulkan $\mathrm{H} 0$ diterima, yang berarti tidak terdapat perbedaan antara orang tua TKA maupun TK-B pada dimensi kelas sosial; dimensi pendidikan formal orang tua, nilai sig 0,988 berarti lebih besar daripada alpha 0,05 , sehingga dapat disimpulkan H0 diterima, yang berarti tidak terdapat perbedaan antara orang tua TK-A maupun TK-B pada dimensi pendidikan formal orang tua; dimensi status rumah orang tua, nilai sig 0,924 berarti lebih besar daripada alpha 0,05, sehingga dapat disimpulkan H0 diterima, yang berarti tidak terdapat perbedaan antara orang tua TK-A maupun TK-B pada dimensi status rumah orang tua.

Dimensi jumlah orang serumah, nilai sig 0,849 berarti lebih besar daripada alpha 0,05, sehingga dapat disimpulkan $\mathrm{H} 0$ diterima, yang berarti tidak terdapat perbedaan antara orang tua TK-A maupun TK-B pada dimensi jumlah orang serumah; dimensi jumlah saudara kandung, nilai sig 0,930 berarti lebih besar daripada alpha 0,05, sehingga dapat disimpulkan H0 diterima, yang berarti tidak terdapat perbedaan antara orang tua TK-A maupun TK-B pada dimensi jumlah saudara kandung; dimensi kepemilikan komputer, nilai sig 0,923 berarti lebih besar daripada alpha 0,05, sehingga dapat disimpulkan $\mathrm{H} 0$ diterima, yang berarti tidak terdapat perbedaan antara orang tua TK-A maupun TK-B pada dimensi kepemilikan komputer.

\section{SIMPULAN}

Keterlibatan orang tua dalam PJJ pada pendidikan dini anak relatif maksimal, sehingga hipotesis pertama yang menyatakan sebaliknya, tidak terbukti; tidak terdapat perbedaan keterlibatan orang tua pada Taman Kanak-Kanak (TK)-A dan TK-B Tarakanita 5 Jakarta Timur, sehingga hipotesis kedua yang menyatakan sebaliknya; faktor demografi mempengaruhi keterlibatan orang tua dalam PJJ anak usia dini. Berarti hipotesis ketiga terbukti.

\section{UCAPAN TERIMA KASIH}

Terimakasih kepada pembimbing yang sudah membantu memberikan masukan pada penelitian ini. Terimakasih kepada para peneliti yang sudah melakukan penelitian dan menjadi rujukan dalam penelitian ini.

\section{DAFTAR PUSTAKA}

Anzani, D. R., Zaeni, I. A. E., Nuqul, F. L., \& ... (2020). Relationship Between Parents' Education Level and Parental Engagement in The Pandemic Period of Covid-19. ... Revolution in Post ..., 30-38. http:/ / conference.um.ac.id/index.php/ksdp/article/view/101

Bacher-Hicks, A., Goodman, J., \& Mulhern, C. (2021). Inequality in household adaptation to schooling shocks: Covid-induced online learning engagement in real time. Journal of Public Economics, 193, 1-32. https://doi.org/10.1016/j.jpubeco.2020.104345

Borup, J., Graham, C. R., \& Davies, R. S. (2013). The Nature of Parental Interactions in an Online Charter School. American Journal of Distance Education, 27(1), 40-55. 
https:/ / doi.org/10.1080/08923647.2013.754271

Cahyati, N., \& Kusumah, R. (2020). Peran orangtua dalam menerapkan pembejalaran di rumah saat pandemi Covod-19. Jurnal Golden Age, 04(1).

Cooper, D.R., \& Schindler, P. . (2014). Business Research Methods (Twelfth ed). McGraw-Hill International Edition.

degli Espinosa, F., Metko, A., Raimondi, M., Impenna, M., \& Scognamiglio, E. (2020). A Model of Support for Families of Children With Autism Living in the COVID-19 Lockdown: Lessons From Italy. Behavior Analysis in Practice, 13(3), 550-558. https://doi.org/10.1007/s40617-020-00438-7

Enterprise, J. (2014). MySQL untuk Pemula. In Jakarta: PT. Elex Media Komputindo. PT. Elex Media Komputindo.

Fedina, N. V., Burmykina, I. V., Zvezda, L. M., Pikalova, O. S., Skudnev, D. M., \& Voronin, I. V. (2017). Study of educators' and parents' readiness to implement distance learning technologies in preschool education in Russia. Eurasia Journal of Mathematics, Science and Technology Education, 13(12), 8415-8428. https:// doi.org/10.12973/ejmste/80802

Fogler, J. M., Normand, S., O'Dea, N., Mautone, J. A., Featherston, M., Power, T. J., \& NissleyTsiopinis, J. (2020). Implementing group parent training in telepsychology: Lessons learned during the COVID-19 pandemic. Journal of Pediatric Psychology, 45(9), 983-989. https://doi.org/10.1093/jpepsy/jsaa085

Ghozali, I. (2018). Aplikasi Analisis Multivariate dengan Program IBM SPSS. Yogyakarta: Universitas Diponegoro. (Edisi 9). Semarang: Badan Penerbit Universitas Diponegoro, 490.

Hoover-Dempsey, K. V., \& Sandler, .H.M. (2014). The social context of Parental involvement: A path to enchanced achievement. Final performance report for OERI grand. 12. https://doi.org/10.1128/AAC.03728-14

Kemendikbud. (2020). Kemendikbud: Orang Tua Memegang Peran Penting dalam Pelaksanaan Belajar dari Rumah. SIARAN PERS Nomor: 147/Sipres/A6/VI/2020. https://www.kemdikbud.go.id/main/blog/2020/06/kemendikbud-orang-tuamemegang-peranan-penting-dalam-pelaksanaan-belajar-dari-rumah

Kemendikbud, \& Menteri Pendidikan dan Kebudayaan Republik Indonesia. (2020). Surat Edaran Nomor 4 Tahun 2020 Tentang Pelaksanaan Kebijakan Pendidikan Dalam Masa Darurat Penyebaran Coronavirus Disease (COVID-19). Republik Indonesia. https:/ / pusdiklat.kemdikbud.go.id/ surat-edaran-mendikbud-no-4-tahun-2020tentang-pelaksanaan-kebijakan- pendidikan-dalam-masa-darurat-penyebarancorona-virus-disease-covid-1-9/

Lilawati, A. (2020). Peran Orang Tua dalam Mendukung Kegiatan Pembelajaran di Rumah pada Masa Pandemi. Jurnal Obsesi: Jurnal Pendidikan Anak Usia Dini, 5(1), 549. https://doi.org/10.31004/obsesi.v5i1.630

Liu, F., Black, E., Algina, J., Cavanaugh, C., \& Dawson, K. (2010). The validation of one parental involvement measurement in virtual schooling. Journal of Interactive Online Learning, $9(2), 105-132$.

O'Brien, J. (2001). The Production of Reality: Essay and Reading on Sosial Interaction. Pine Forge Press.

Palmer, AG and Potter, P. (2007). Simple Guides Takanan Darah Tinggi. EGC.

Purandina, I. P. Y., \& Winaya, I. M. A. (2020). Pendidikan Karakter di Lingkungan Keluarga Selama Pembelajaran Jarak Jauh pada Masa Pandemi COVID-19. Cetta: Jurnal Ilmu Pendidikan, 3(2), 270-290. https://doi.org/https://doi.org/10.37329/cetta.v3i2.454

Sarwono, J. (2012). Metode Riset Skripsi Pendekatan Kuantitatif. PT Elex Media Komputindo.

Sekaran, U., B. (2016). Research Method for Business: A Skill Buiding Approach (Seventh er). John Wiley \& Sons Ltd.

Shadiqien, S. (2020). Efektivitas Komunikasi Virtual Pembelajaran Ddaring dalam Masa PSBB (Studi Kasus Pembelajaran Jarak Jauh Produktif Siswa SMK Negeri 2 Banjarmasin). MUTAKALILIMIN; Jurnal Ilmu Komunikasi, 3(1), 11-21. https://ojs.uniska- 
bjm.ac.id/index.php/mutakallimin/article/view/3573

Stevens, M., \& Borup, J. (2015). Parental engagement in online learning environments: A review of the literature. Advances in Research on Teaching, 25, 99-119. https:/ / doi.org/10.1108/S1479-368720150000027005

Wardhani, T.Z.Y., \& Krisnani, H. (2020). Optimalisasi peran pengawasan orangtua dalam pelaksanaan sekolah online di masa pandemi Covid-19. Prosiding Penelitian $\mathcal{E}$ Pengabdian Kepada Masyarakat, 7(1), 48-59.

Widarjono, A. (2013). Analisis Multivariat Terapan Dengan Program SPSS (Edisi Kedu). UPP STIM YKPN.

World Health Organization. (2020). Coronavirus disease 2019. World Health Organization. https://www.who.int/emergencies/diseases/novel-coronavirus-2019

Yulianingsih, W., Suhanadji, S., Nugroho, R., \& Mustakim, M. (2020). Keterlibatan Orangtua dalam Pendampingan Belajar Anak selama Masa Pandemi Covid-19. Jurnal Obsesi: Jurnal Pendidikan Anak Usia Dini, 5(2), 1138-1150. https:// doi.org/10.31004/obsesi.v5i2.740 